\title{
THE CATALYSIS OF WATER PHOTO-OXIDATION BY HEAVY METAL HEXACYANIDES
}

\author{
K. TENNAKONE*, S. WICKRAMANAYAKE*, M.U. GUNASEKARA \\ Department of Pbysics, University of Rubuna, Matara, Sri Lanka.
}

AND

R. M. PATHIRANA

Department of Chemistry, University of Rubuna, Matara, Sri Lanka.

(Date of receipt : 11.07.86)

(Date of acceptance : 05.01.87)

\begin{abstract}
A number of heavy metal hexacyanides are tested for their ability to catalyse photo-oxidation of water with bipy ${ }_{3} \mathrm{Ru}^{2+}$ as the sensitizer and $\mathrm{K}_{2} \mathrm{~S}_{2} \mathrm{O}_{8}$ as the sacrificial agent. Strongest catalytic activity is seen in $\mathrm{Zn}_{3}\left(\mathrm{Fe}(\mathrm{CN})_{6}\right)_{2}, \mathrm{Cd}\left(\mathrm{Fe}(\mathrm{CN})_{6}\right)_{2}$ and $\mathrm{Fe}_{3}\left(\mathrm{Fe}(\mathrm{CN})_{6}\right)_{3}$. Semiconducting properties of heavy metal hexacyanides and their relevance to catalytic activity are discussed.
\end{abstract}

\section{Introduction}

Photo-oxidation of water in the presence of sacrificial agents has attracted much attention as models of photosystem II in natural photosynthesis. ${ }^{1,2,3,4,5,6}$ Heterogeneous sensitizers (semiconductors) generally photo-oxidise water under sacrificial conditions even in the absence of other catalysts. $2,3,6$ However, in the case of homogeneous sensitizers the presence of catalysts become essential for oxygen generation. ${ }^{1,3,4,8}$ It is known that one electron oxidant tris $\left(2\right.$ ' - bipyridyl ruthenium (III) $\left(\right.$ bipy $_{3} \mathrm{Ru}^{3+}$ ) could bring 4 - electron transfer leading to photo-oxidation of water in the presence of catalysts such as $\mathrm{RuO}_{2}, \mathrm{IrO}_{2}$ and $\mathrm{MnO}_{2} \cdot{ }^{9-11}$. Recently it has also been noted that prussian blue $(\mathrm{PB})$ could also catalyse the same reaction with persulphate as the electron acceptor. ${ }^{12}$. A suspension of $\mathrm{PB}$ in a solution containing bipy ${ }_{3} \mathrm{Ru}^{2+}$ and $\mathrm{K}_{2} \mathrm{~S}_{2} \mathrm{O}_{8}$ photogenerate $\mathrm{O}_{2}$ via following reaction scheme. ${ }^{12}$

$$
\begin{array}{lll}
\text { bipy }_{3} \mathrm{Ru}^{2+}+\mathrm{S}_{2} \mathrm{O}_{8}^{-} & \mathrm{h} v & \text { bipy }_{3} \mathrm{Ru}^{3+}+\mathrm{SO}_{4}^{-}+\mathrm{SO}_{4}{ }^{2-} \\
\text { bipy }_{3} \mathrm{Ru}^{2+}+\mathrm{SO}_{4}^{-} & \rightarrow & \text { bipy }_{3} \mathrm{Ru}^{3+}+\mathrm{SO}_{4}^{2-} \\
4 \text { bipy }_{3} \mathrm{Ru}^{3+}+2 \mathrm{H}_{2} \mathrm{O} & \stackrel{\mathrm{PB}}{\rightarrow} & 4 \text { bipy }_{3} \mathrm{Ru}^{2+}+4 \mathrm{H}^{+}+\mathrm{O}_{2}^{4}
\end{array}
$$

* Photochemistry Group, Institute of Fundamental Studies, Hantana, Sri Lanka. 
We have tested a number of other water insoluble heavy metal ferroand ferri-cyanides (PB type structure) for the above catalytic activity and found that $\mathrm{Zn}_{3}\left(\mathrm{Fe}(\mathrm{CN})_{6}\right)_{2}, \quad \mathrm{Cd}_{3}\left(\mathrm{Fe}(\mathrm{CN})_{6}\right)_{2}$ and $\mathrm{Fe}_{3}\left(\mathrm{Fe}(\mathrm{CN})_{6}\right)_{3}$ are superior to PB. It was also noted that $\mathrm{Cu}_{4}\left(\mathrm{Fe}(\mathrm{CN})_{6}\right)_{2}$ behave differently, this material does not catalyse water oxidation reaction with persulphate in the presence of bipy ${ }_{3} \mathrm{Ru}^{2+}$. However, in the absence of bipy ${ }_{3} \mathrm{Ru}^{2+}$, $\mathrm{Cu}_{4}\left(\mathrm{Fe}(\mathrm{CN})_{6}\right)_{2}$ catalyses photo-oxidation of water with sacrifice of persulphate. Again $\mathrm{Cu}_{4}\left(\mathrm{Fe}(\mathrm{CN})_{6}\right)_{2}$ is found to catalyse sacrificial photoreduction of water. These observations can be attributed to semiconducting properties of $\mathrm{Cu}_{4}\left(\mathrm{Fe}(\mathrm{CN})_{6}\right)_{2}$.

\section{Experimental}

Ferro - and ferri- cyanides of several heavy metals ( $\mathrm{Zn}, \mathrm{Cd}, \mathrm{Cu}, \mathrm{Fe}, \mathrm{Mn}, \mathrm{Cr}$ ) were prepared by double decomposition of the solutions of their salts (Chloride or Sulphate, Analar) with a solution of $\mathrm{K}_{4} \mathrm{Fe}(\mathrm{CN})_{6}$ or $\mathrm{K}_{3} \mathrm{Fe}(\mathrm{CN})_{6}$. The metal salt was kept in large excess to prevent the formation of double salts containing K. ${ }^{13}$. Precipitates were washed and dried at $90^{\circ} \mathrm{C}$. The photochemical reactions were carried out in a thermostated $\left(26^{\circ} \mathrm{C}\right)$ quartz cell $(35 \mathrm{ml}$ ) equipped with a polarographic detector (Applied Photophysics). The solution contained $9.2 \times 10^{-3}$ mol dm${ }^{-3}$ of $\mathrm{K}_{2} \mathrm{~S}_{2} \mathrm{O}_{8}$ and various concentration of different catalysts. All solutions were purged with argon and the cell was sealed before irradiation. The light source used was a $90 \mathrm{~W}$ medium pressure mercury lamp (UV and IR filtered off). Light intensities were measured with an International Light IL 700 Radiometer.

To measure the electrical conductivity of $\mathrm{Cu}_{4}\left(\mathrm{Fe}(\mathrm{CN})_{6}\right)_{2}$, the material in the powder form was compacted between stainless steel electrodes to a pressure $\sim 80 \mathrm{~K}$ bar, in a glass tube (diameter $\sim 0.6 \mathrm{~cm}$, pellet length $\sim 0.4 \mathrm{~cm}$ ), the ends of the tube were sealed with epoxy resin and the resistance at different temperature was measured with an ohm-meter. The diffuse reflectance spectra of the catalyst in the dry powder form or the absorption spectra of the suspensions were determined using an Unicamp SP 500 Series II spectrophotometer.

\section{Results and Discussion}

As the catalyst and bipy ${ }_{3} \mathrm{Ru}^{2+}$ absorb light in the same spectral region, the reaction rates vary with the concentration of the catalyst and in each case an optimum concentration is found to exist. ${ }^{12}$ Figure 1 indicates the variation of the initial reaction rate with the concentration of $\mathrm{Zn}_{3}\left(\mathrm{Fe}(\mathrm{CN})_{6}\right)_{2}$. Figure 2 shows $O_{9}$ photogeneration with different catalysts at their optimum concentrations $\left(\mathrm{pH} 7\right.$, as in $\mathrm{PB}^{12}$ the reaction rates are 


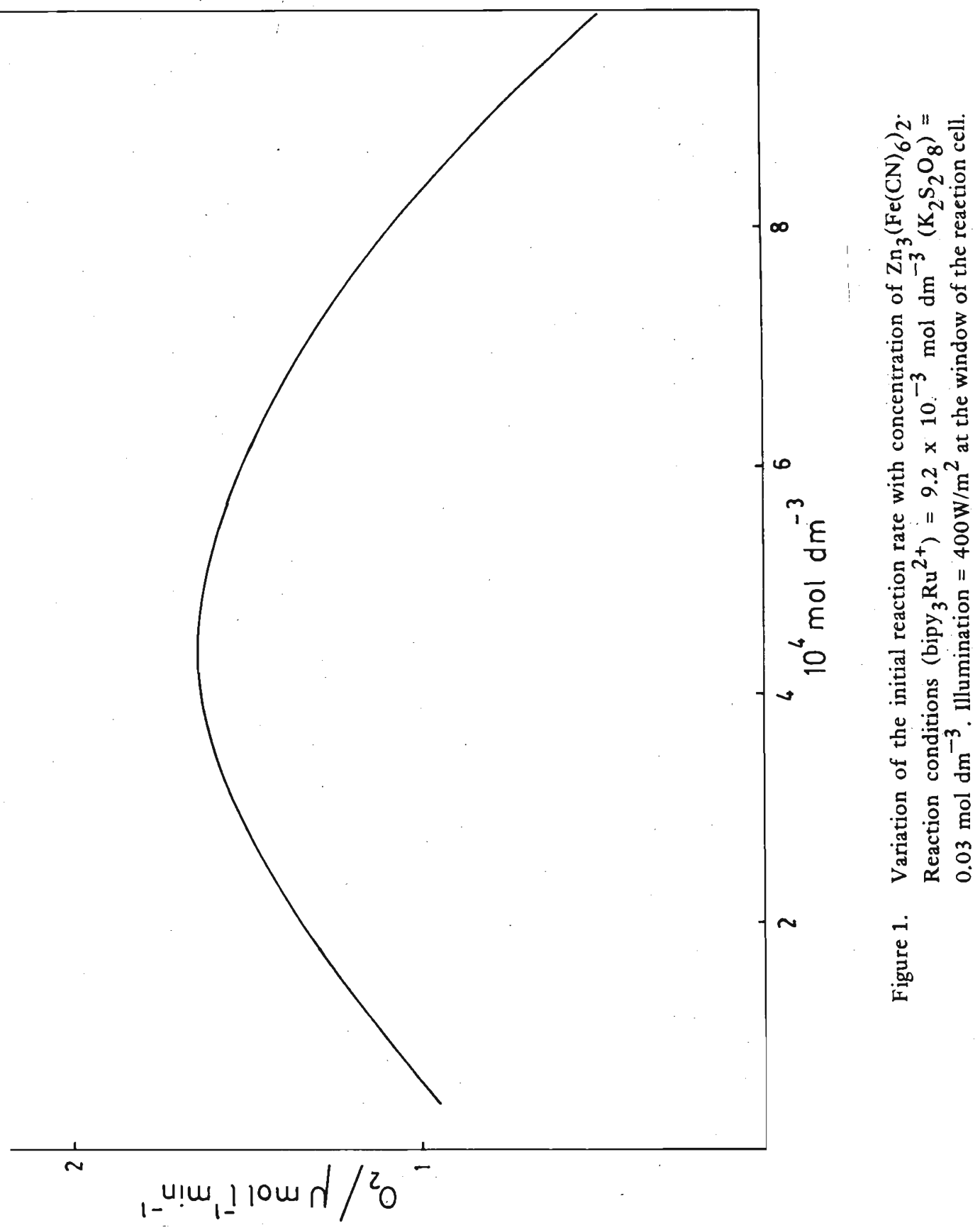




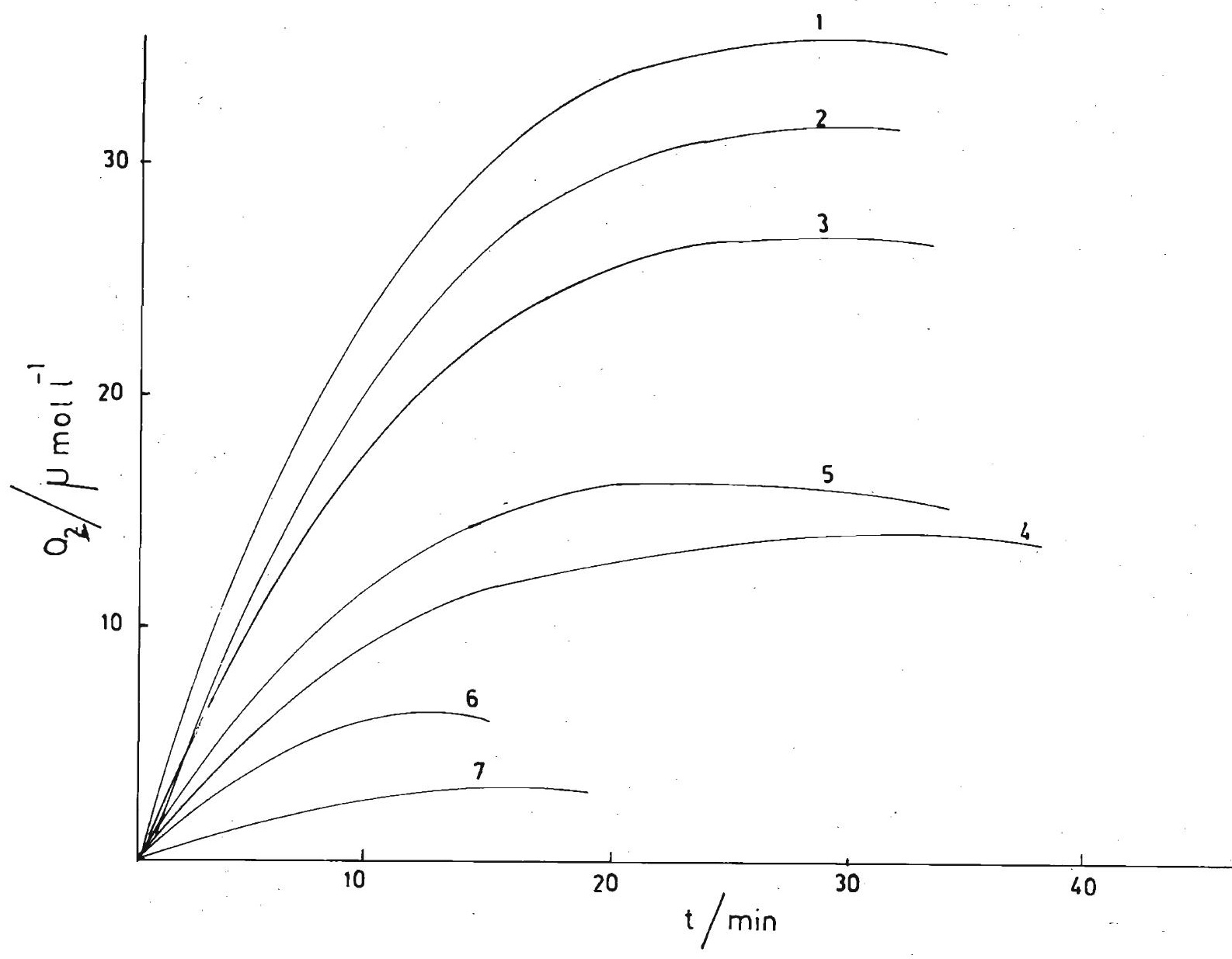

Figure 2. Photogeneration of $\mathrm{O}_{2}$ from different catalysts at their optimum concentrations (other conditions as in Figure 1).

1. $\mathrm{Zn}_{3}\left(\mathrm{Fe}(\mathrm{CN})_{6}\right)_{2} \quad(4.3)$

2. $\mathrm{Cd}_{3}\left(\mathrm{Fe}(\mathrm{CN})_{6}\right)_{2} \quad(3.8)$

3. $\mathrm{Fe}_{3}\left(\mathrm{Fe}(\mathrm{CN})_{6}\right)_{3} \quad(4.0)$

4. $\mathrm{PB} \quad(3.6)$

5. $\mathrm{Cu}_{3}\left(\mathrm{Fe}(\mathrm{CN})_{6}\right)_{3} \quad(4.8)$

6. $\mathrm{Cr}_{4}\left(\mathrm{Fe}(\mathrm{CN})_{6}\right)_{3} \quad$ (3.9)

7. $\mathrm{Mn}_{4}\left(\mathrm{Fe}(\mathrm{CN})_{6}\right)_{2} \quad(3.0)$

Numbers given inside the brackets are catalyst concentrations in $10^{4} \mathrm{~mol} \mathrm{dm}^{-3}$. 
maximum when the $\mathrm{pH}$ is $\sim 7$ ), the other conditions kept constant. The highest initial reaction rate and the highest final $\mathrm{O}_{2}$ concentration are obtained with $\mathrm{Zn}_{3}\left(\mathrm{Fe}(\mathrm{CN})_{6}\right)_{2}, \mathrm{Cd}\left(\mathrm{Fe}(\mathrm{CN})_{6}\right)_{2}$ and $\mathrm{Fe}_{3}\left(\mathrm{Fe}(\mathrm{CN})_{6}\right)_{3}$ (Berlin Green) which are superior to $\mathrm{PB} . \mathrm{Zn}_{3}\left(\mathrm{Fe}(\mathrm{CN})_{6}\right)_{2}$ absorbs more in the absorption region of bipy ${ }_{3} \mathrm{Ru}^{2+}$ than PB (Figure 3 ). Again as the particle sizes (estimated from the sedimentation ratio) of all the compounds are found to be nearly same, the observed difference in catalytic activity could not arise as a result of any difference in the degree of dispersion.

Cupric ferrocyanide behave differently from other compounds. Here in the presence of bipy ${ }_{3} \mathrm{Ru}^{2+}$ with $\mathrm{K}_{2} \mathrm{~S}_{2} \mathrm{O}_{8}$ as the sacrificial agent, $\mathrm{O}_{2}$ is not photogenerated. But in the absence of bipy ${ }_{3} \mathrm{Ru}^{2+}$ (ie, only $\mathrm{K}_{2} \mathrm{~S}_{2} \mathrm{O}_{8}$ ), $\mathrm{O}_{2}$ is generated with visible light (Figure 4 ). All the other hexacyanides we have examined evolve $\mathrm{O}_{2}$ only if bipy $\mathrm{Ru}^{2+}$ is present in addition to $\mathrm{K}_{2} \mathrm{~S}_{2} \mathrm{O}_{8}$. Again with sacrificial electron donors. 'o, acetic acid, $\mathrm{Cu}_{4}\left(\mathrm{Fe}(\mathrm{CN})_{6}\right)_{2}$ is found to catalyse photoreduction of water (Figure 5).

Hexacyanides exhibit semiconduction which is often enhanced by adsorbed water. ${ }^{13,14,15}$ Although there are exceptions, the general trend is, ferrocyanides are $n$-type and ferricyanides are $\mathrm{p}$-type. ${ }^{15} \mathrm{~PB}$ is known to have $p$-type behaviour. ${ }^{16,17}$ Thermoelectric and Hall tests indicate that $\mathrm{Zn}_{3}\left(\mathrm{Fe}(\mathrm{CN})_{6}\right)_{2}, \mathrm{Cd}\left(\mathrm{Fe}(\mathrm{CN})_{6}\right) 2$ and $\mathrm{Fe}_{3}\left(\mathrm{Fe}(\mathrm{CN})_{6}\right)_{3}$ are $\mathrm{p}$-type, where as $\mathrm{Cu}_{4}\left(\mathrm{Fe}(\mathrm{CN})_{6}\right)_{2}$ is $\mathrm{n}$-type ${ }^{15}$ It is likely that higher hole mobility favours catalytic activity towards photo-oxidation of $\mathrm{H}_{2} \mathrm{O}$ as holes can get more easily accumulated in a $\mathrm{p}$-type material.

The temperature variation of the electrical conductivity of $\mathrm{Cu}_{4}\left(\mathrm{Fe}(\mathrm{CN})_{6}\right)_{2}$ is presented in Figure 6(a), the thermal activation energy is found to be $0.57 \mathrm{eV}$ and the diffuse reflectance spectrum (Figure $6 \mathrm{~b}$ ) suggests band gap $\sim 2.0 \mathrm{eV}$. The catalysis of sacrificial photo-oxidation and reduction (visible light) by this material can be understood as in other semiconductors and band positions should be favourably located. When bipy ${ }_{3} \mathrm{Ru}^{2+}$ is present $\mathrm{O}_{2}$ generation is inhibited possibly because $\mathrm{Cu}_{4}\left(\mathrm{Fe}(\mathrm{CN})_{6}\right)_{2}$ effectively catalyse $\mathrm{O}_{2}-$ depleting reverse reaction.

All the above compounds remain stable in persulphate $(9 \mathrm{pH} \lesssim 10)$. The strongest resistance to oxidation is seen in Berlin Green, which is unaffected even by conc. boiling $\mathrm{HNO}_{3}$.

We are not in a position to give a detailed explanation as to why $\mathrm{PB}$ type complexes catalyse photo-oxidation of water. Perhaps the combination of semiconducting and zeolitic properties play an important role. 
K. Tennakone et al.

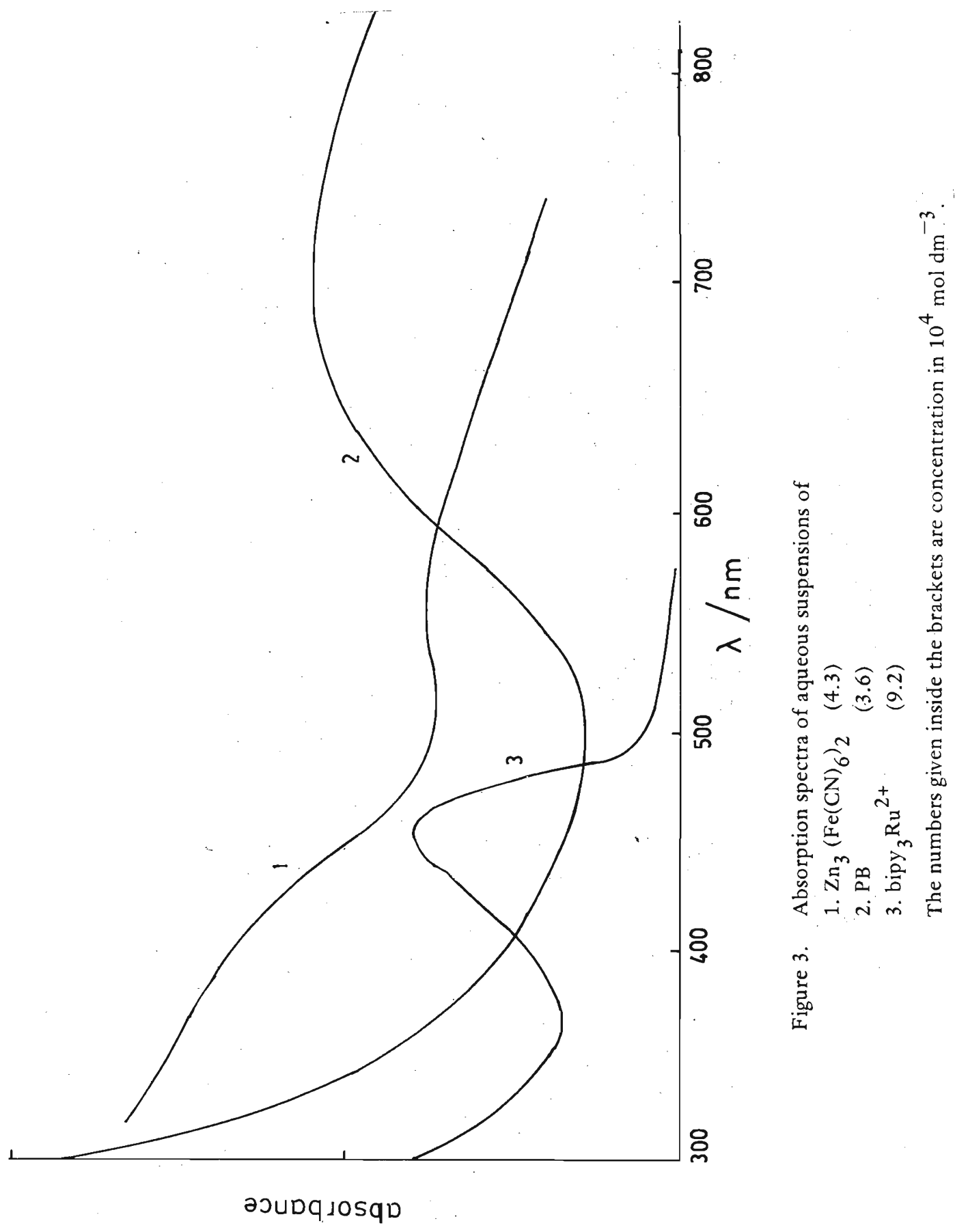




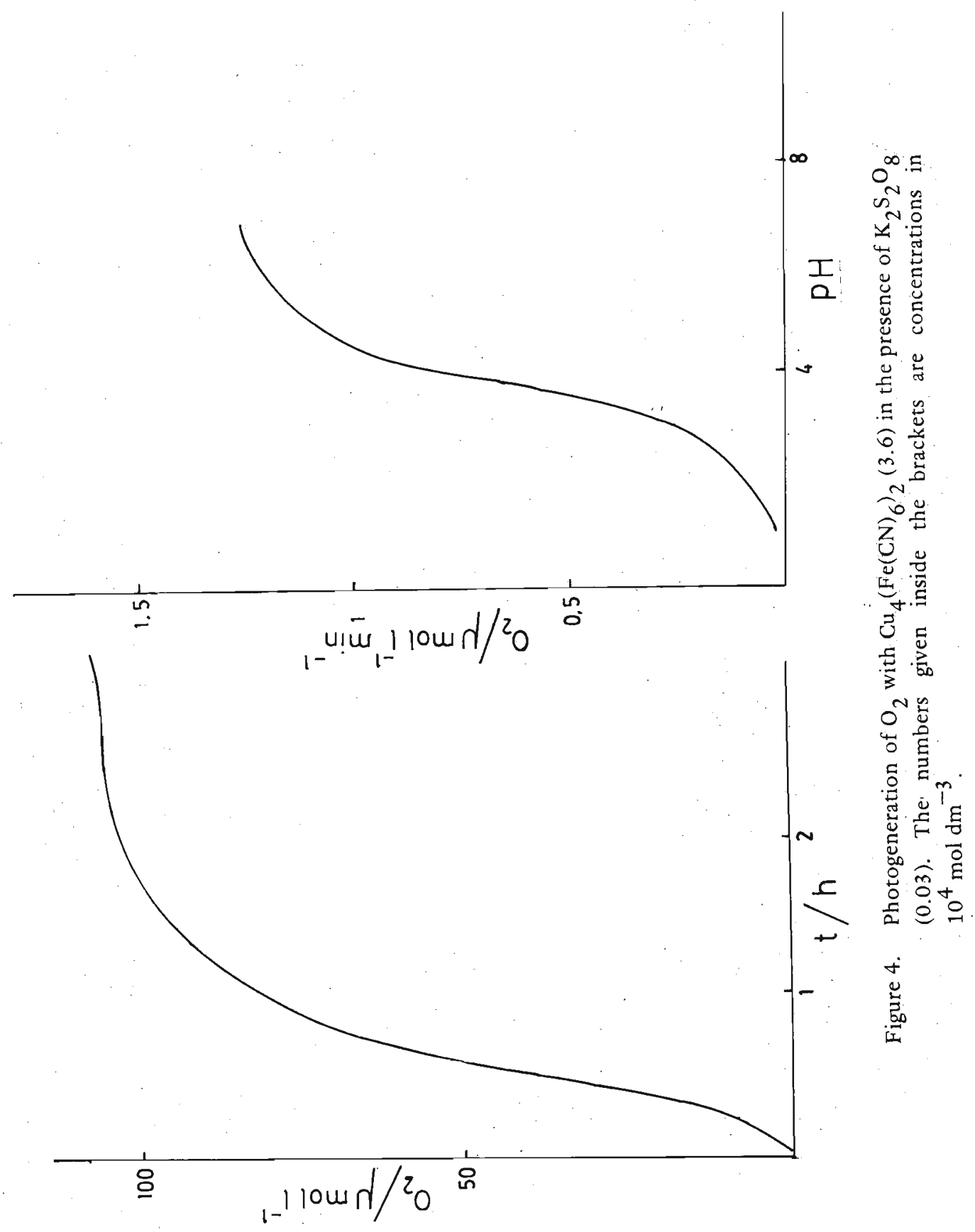




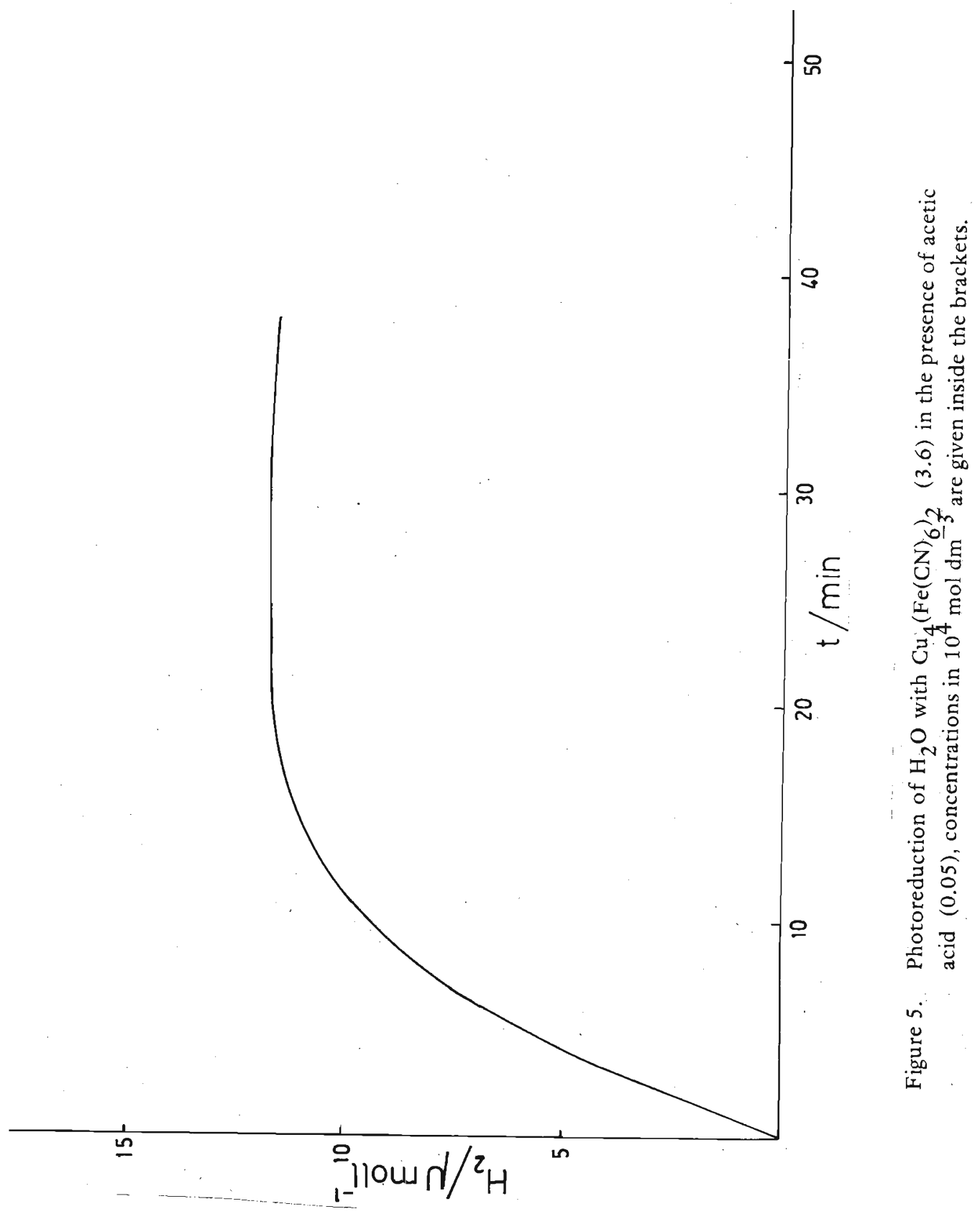




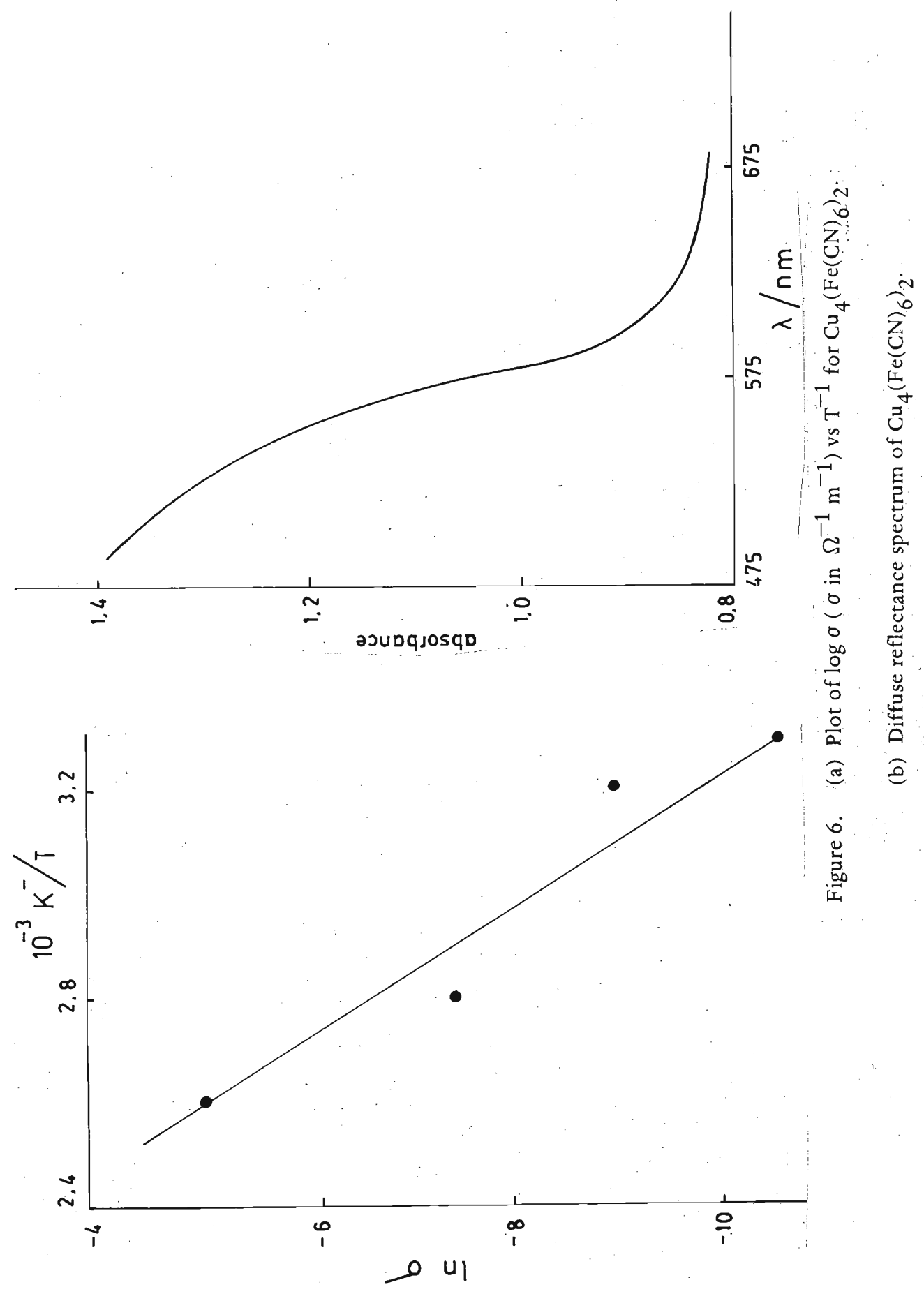




\section{References}

1. 'Energy Resources through Photochemistry and Catalysis', ed. M. Gratzel, Academic Press, New York, 1983.

2. DARWENT, J. R. (1981) J. Chem. Soc. Faraday Trans, 2, 77:1703.

3. ERBS, W., DESILVESTRO, J., BORGARELLO, E. \& GRATZEL, M. (1984) J. Pby. Chem., 88: 4001.

4. HARRIMAN, A. (1984) Platinum Metals Rev., $27: 102$.

5. CHRISTENSEN, P. A., HARRIMAN, A., PORTER, G. \& NETA, P. (1984) J. Chem. Soc. Faraday Trans, 2, 80: 1451.

6. DIMITRIJEVIE, N. M. LI, S. \& GRATZEL, M. (1984) J. Am. Chem. Soc. 106: 6565.

7. SHAFIROVICH, V. Ya., KHANNOV, N.K. \& STRELETS, V. V. (1980) Nouv. J. Chim, 4: 81.

8. HARRIMAN, A., PORTER, G. \& WALTERS, P. (1981) J. Cbem. Soc. Faraday Trans, 2, 77: 2373.

9. KIWI, J. \& GRATZEL, M. (1978) Angew, Chem. Int. Ed. Engl., 17: 860.

10. LEHN, J.M., SANVAGE, J.P. \& ZIESSEL, R. (1979) Nouv. J. Cbim., 3: 423.

11. ' OKUNO, Y., YONEMITSU, O. \& CHIBA, Y. (1983) Chem. Lett., 815.

12. CHRISTENSEN, P. A., HARRIMAN, A., NETA, P. \& RICHOUX, M. C. (1985) J. Chem. Soc. Faraday Trans, 1, 81: 2461.

13. TENNAKONE, K. \& KALUARACHCHI, P. (1980) Pbys. Stat. Sol. (a), 58: K55.

14. TENNAKONE, K. \& ARIYASINGHE, W.M. (1981) J. Chem. Pbys. 74: 4661.

15. TENNAKONE, K. (1983) J. Pbys. C., 16: L 1193.

16. INOUE, M. \& YANAGISAWA, S. (1974) J. Inorg. Nucl. Chem, 36: 1409.

17. GANGULI, S. \& BHATTACHARTA, M. (1983) J: Chem. Soc. Faraday Trans. 1. 79: 1513. 